\title{
Use of Treated Water from Sewage Treatment Plants in Irrigation by using Solar/Grid Powered Micro Irrigation Infrastructure
}

\author{
Neeraj Sharma \\ Executive Engineer \\ Command Area Development \\ Authority \\ Kurukshetra, India
}

\author{
Rajiv Bansal \\ Chief Engineer \\ Command Area Development \\ Authority \\ Panchkula, India
}

\author{
Amit Kumar Raghuvanshi \\ Superintending Engineer \\ Command Area Development \\ Authority \\ Kaithal, India
}

\begin{abstract}
With a view of augmenting water for assured supply to the every field, a new intervention has been proposed for the reuse of treated waste water from the existing Sewage Treatment Plants for the use of water in the best alternative which will help in enhancing the irrigation in agriculture sector. Working on these lines, Installation of Solar/Grid Powered Micro Irrigation Infrastructure has been proposed by selecting the nearby area of the existing Sewage Treatment Plant by providing common infrastructure with components Retention tank near outlet head of STP, Pumping Unit (Grid/Solar Powered), Filtration units, HDPE pipe network/Hydrant/Outlet assembly, Valves etc with Drip/Sprinkler irrigation sets. The Solar Power System is proposed to be connected with the utility power grid so that the energy generated by the solar modules, whenever not required for operation of the pumping system or is in excess of requirement, can be sent to the Utility Grid through bidirectional meter.
\end{abstract}

Keywords: Solar/Grid, Micro Irrigation, Sewage Treatment Plant (STP), Irrigation Efficiency, High Tension Line

\section{INTRODUCTION}

Growing Economy, Urbanization, and Population along with rapid industrialization has increased the production of waste water many folds all over. The disposal of untreated waste water has therefore, become a serious problem as it affects the fresh water resources and human health. A large volume of waste water is produced in the cities \& towns. In existing sewage system, domestic sewage and industrial effluents including washings from cattle sheds etc. flows through the sewerage system, which pollute land and water resources around towns and cities. Due to unorganized disposal of waste water, which is drained into rivers have eventually deteriorated the quality of freshwater resources besides creating serious problem of environmental hazard by polluting surface and sub-surface water, thereby also endangering the aquatic life as well as the human population living on the banks of these rivers. Due to over exploitation of ground water for agriculture, subsurface water is declining at an alarming rate. Water table is going down which creates endangered to the sustainability of the agriculture production system. Ground water along with existing water resources are proving inadequate, therefore there is need to tap and encourage alternate means which could provide irrigation to crops. In light of this treated sewage water is the best alternative which will help in irrigation. This paper is envisaging the implementation of a project on treated water from the STP's used in agricultural fields for irrigation purposes, which was otherwise going waste in to various rivers, besides polluting them. Irrigation to crops with secondary treated sewage water may also supply nutrients to the crops which mean less of inorganic fertilizers will be required along with saving on power and diesel consumption as supply of water from STP's will mean lesser dependence on tube wells for pumping out ground water, thus lowering production costs which in turn means higher profit for farmer community. Underground Pipe Line System (UGPS) will be installed in the farmer fields with command area, depending upon the discharge of each STP. Regular monitoring of quality of water is being assured at Sewage Treatment Plants, which has been found fit for irrigation purposes. Most of the toxic elements that are generally found in treated sewage water are below the permissible limits for use in agriculture for all the Sewage Treatment Plants.

\section{METHODOLOGY}

Solar/Grid Powered Micro Irrigation Infrastructure in the Sewage Treatment Plant Commands has been installed by providing Retention tank near outlet head, Pumping Unit (Grid/Solar Powered), Filtration units, HDPE pipe network/Hydrant/Outlet assembly, Valves etc. in the command area of Sewage Treatment Plant, as shown in layout plan Figure-1. Drip/Sprinkler irrigation sets will be installed by the individual farmers in their farm holdings by availing the benefits of subsidy. It is proposed to take water from Sewage Treatment Plant outlet through underground pipeline with gravity and to store the same in the retention tank of appropriate size within the Sewage Treatment Plant area. Solar/Grid powered pumping system connected through net metering has been installed nearby the tank with proper filtration systems to avoid any chocking. Water has been carried to entire area selected nearby the Sewage Treatment Plant through HDPE pipe line network under pressure. The entire pipe network has been buried under ground at 3 feet deep to avoid land acquisition. Water with the requisite pressure for running of the drip/sprinkler set has been made available to each shareholder at his farm holding through the common infrastructure to be operated \& maintained by the Water User's Associations. 
Figure 1

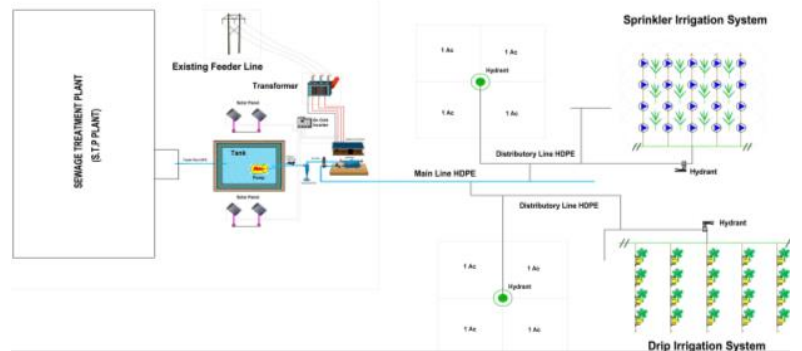

\section{Design Parameters.}

Modified penman method has been used to find out crop water requirement and computed the peak water requirement in rabi \& kharif season. In this scheme average water requirement of $2 \mathrm{~mm} / \mathrm{day}$ has been considered. Considering this crop water requirement and capacity of Sewage Treatment Plant each component of this scheme shall be designed in such a manner that minimum operating pressure of $2.5 \mathrm{Kg} / \mathrm{cm}^{2}$ available to the farmers on their farm gate. Size of the retention tank has been designed by considering discharge of the outlet and volume of water accumulated as effective outflow in million litres per day. Further operation time of Sewage Treatment Plant per day has also been considered. A feeder pipe of required size in appropriate length has been provided from STP outlet to the storage tank by gravitational flow. Solar pumping system is a vital part of this scheme and in this scheme grid connected solar powered pump has been considered to reduce the cost of electricity of appropriate size. At least one pump is provided in a block of area 40 to 50 Hactare. Solar pumps of the capacity up to 10 to $20 \mathrm{HP}$ is preferred with average working of 14 hours/day. The HP of pump set required is based upon design discharge and total operating head. The total operating head is sum of total static head, friction loses worked out with hazen-williams equation in pipeline network and losses in filtration unit. Pipes in main line and sub-main shall not be below $110 \mathrm{~mm}$ (OD) and the size shall be decided based on the criteria to limit the friction loss in the main \& sub main keeping the minimum flow velocity in the pipeline as $0.6 \mathrm{~m} / \mathrm{sec}$.

$$
\begin{aligned}
& \text { HP of pump set }=\frac{\mathrm{QxH}}{75 \mathrm{e}} \\
& \begin{array}{l}
\mathrm{Q}=\text { discharge (in LPS) } \\
\mathrm{H}=\text { head (in meter) } \\
\mathrm{e}=\text { Pumping efficiency }
\end{array}
\end{aligned}
$$

Solar PV array of at least 1100wp capacities has been installed per HP rating of pumping sets and total capacity of the Solar pv array for operation of solar pumping sets has been worked out in such a manner that total annual solar energy generation from the PV power system in no case be lesser than the total energy requirement to run the Micro Irrigation System and there is no net import of energy from the utility grid on annual basis. Total Capacity of the Solar PV array to be installed on each STP outlet scheme for operation of the Solar Pumping Set(s) will be worked out in such a manner that total annual solar energy generation from the PV Power System is in no case lesser than the total annual energy requirements of the MI scheme including auxiliary requirements and there is no net import of energy from the Utility Grid on annual basis.

The output power of SPV would be fed to the inverters for conversion of the DC produced by SPV array to AC for operation of the motor pump sets and feeding the same into the nearest electricity grid through $11 \mathrm{KV}, 24$ hours energized HT independent line after synchronization when in excess of requirement. A hydrant assembly has been provided with minimum 110 size for the land holding of every share holder with provision of at least one hydrant for every 04 acres or less.

\section{Conclusion}

Significant irrigation from tube wells are being done in various parts. Water use efficiency is very poor and ground water wastage in shape of flood irrigation is being over exploited. It also causes wastage of electricity. Use of micro irrigation infrastructure on Sewage Treatment Plant will reduce the use of tube wells by which ground water will be saved and treated water will be used which was otherwise going waste. More area can be brought under irrigation by using Sewage Treatment Plant treated water, which was otherwise either rain fed or irrigated by tube wells. Where there is no possibility of irrigation through canal commands and ground water is very low, the only solution is creating of Micro Irrigation infrastructure on Sewage Treatment Plant outlets. Where the ground water table is very high with brackish water, there are chances of creating the situation of water logging, which is harmful for soil properties, in these areas, it is essentially required to minimize the flood irrigation by replacing with micro irrigation. Hence, by installation of Solar/Grid Powered Micro Irrigation Infrastructure in the Sewage Treatment Plant Commands through integrated approach of supply management and demand management, yield $\&$ net sown area will increase, dependency of tube well $\&$ overexploitation of ground water will decrease, saving of highly subsidized electricity and above all change of the mindset of the farmers towards the use of available water judiciously.

\section{References}

1. Bucks, D.A. 1993. Micro Irrigation- Worldwide usage report. In Proceedings of Workshop on Micro Irrigation, Sept 2 1993. 15 $5^{\text {th }}$ Congress on Irrigation and Drainage.

2. Batchelor, C., Lovell, C.\& Murata, Water User Efficiency of Simple Subsurface Irrigation Systems, In : Proceedings of $7^{\text {th }}$ International Conference on Water and Irrigation, 13-16, May, 1996

3. Neeraj Sharma, Rajiv Bansal, for Installation of Solar/Grid Powered Micro Irrigation Infrastructure in the Canal Commands in International Journal of Engineering and Technology Volume-56- February 2018.

4. Design and Optimization of Irrigation Distribution Networks Food and Agriculture Organisation of the United Nations irrigation and Drainage Paper.

5. Howell, T.A. (2001), Enhancing water use efficiency in irrigated agriculture, Agron J 93 (2), 281-289.

6. Hsiao T.C., P. Steduto, and E. Fereres (2007), A Systematic and quantitative approach to improve water use efficiency in agriculture, Irrg. Sci., 25(3), 209-232, doi:10.1007/s00271-007-0063-2. 